\title{
Book Review: Our Unprotected Heritage: Whitewashing the Destruction of our Cultural and Natural Environment
}

Mark Walters

Heritage Research Center, Stephen F. Austin State University

Follow this and additional works at: https://scholarworks.sfasu.edu/ita

Part of the American Material Culture Commons, Archaeological Anthropology Commons, Environmental Studies Commons, Other American Studies Commons, Other Arts and Humanities Commons, Other History of Art, Architecture, and Archaeology Commons, and the United States History Commons

Tell us how this article helped you.

This Article is brought to you for free and open access by the Center for Regional Heritage Research at SFA ScholarWorks. It has been accepted for inclusion in Index of Texas Archaeology: Open Access Gray Literature from the Lone Star State by an authorized editor of SFA ScholarWorks. For more information, please contact cdsscholarworks@sfasu.edu. 


\section{Book Review: Our Unprotected Heritage: Whitewashing the Destruction of our}

Cultural and Natural Environment

\section{Creative Commons License}

\section{(c) (1) \&}

This work is licensed under a Creative Commons Attribution-NonCommercial 4.0 International License 


\section{BOOK REVIEW \\ Our Unprotected Heritage: \\ Whitewashing the Destruction of our Cultural and Natural Environment}

Thomas F. King, Left Coast Press, Walnut Creek, California, 2009

\section{Reviewed by Mark Walters}

Before becoming involved in archeology, I was a commercial nurseryman for thirty years in East Texas. Finally though, I had my fill of fighting weather, unstable markets, pests and yes, government agencies. After retirement I sought what I thought would be tranquility in the field of archeology. Archeology was a topic that I had been interested in since I was a teenager and I thought it would provide the peace-of-mind I was seeking. Wrong again.

Don Quixote had his horse Rocinante, and I have my truck, and we are all looking pretty beat-up from charging windmills. Like Thomas F. King, my particular windmill is the destruction of our cultural environment. When I first became serious about archeology, I was motivated by the concern for protecting a specific site on my property. Since then, I have become involved with various organizations that seek to preserve and protect all significant archeological sites. However, through the years, I have become increasingly dismayed at the failure of our system of laws and regulations to provide adequate protection for those sites.

In his latest book "Our Unprotected Heritage," Dr. King lashes out at what he describes as "whitewashing the destruction of our cultural and natural environment," not just the destruction of those environments, but the blatant effort by regulatory agencies to cover up that destruction. Dr. King, a self-proclaimed curmudgeon, draws on forty years of experience in the Cultural Resource Management (CRM) field to make his case. Dr. King has served as a government worker, heritage consultant, and advocate for local communities, and is widely respected for his popular books on CRM (King 2000, 2002, 2003, 2004, 2005).

Dr. King places blame on the guardians of our heritage, the often-uncaring government employees and self-serving agencies, all of who conspire to keep our heritage unprotected by promoting unintelligible (often- contradictory) regulations. This was not the intent of the original legislation but rather what it has evolved into, and increasingly it has become more so through time. In this book, he points out what he thinks is wrong with the system and what we might actually do to make it work. His injection of personal examples of how the system doesn't work should be an eye-opener to those schooled in resource management who believe all is well in this "best of all possible worlds." In fact, it is Dr. King's broad and lengthy CRM experience that makes this book unique.

From my personal experiences, I have learned that the government agencies do not want or appreciate your input or inquiries. In my case, in seeking information on a local project from the state of Texas regulatory agency, I had to resort to an Open Records Act request and even then my request was labeled "onerous." What I grudgingly did learn, for the year 2005, was that the state agency in question reviewed 6450 projects, not the 13,000 they advertised. Furthermore, the number of projects out of the 6450 for which an archeological survey was requested was 368. No information was forthcoming concerning the actual number of sites recommended for testing to evaluate their research significance, or the number of sites recommended for data recovery to mitigate their loss or destruction because of a proposed development. The number of instances in that year (or any other year that I could find) that the agency imposed fines or penalties on developers that had damaged sites proposed for development, or on looters that had dug on sites on state property, was zero. 
This state agency projects themselves as enforcement tigers but in reality they are only "paper tigers," as the record clearly shows, forcing them to practice "hold-um or fold-um" strategies to avoid embarrassing political conflicts. In the meantime more sites are destroyed or determined by the state, with or without input from the concerned public citizen, to not be important.

Dr. King primarily deals with what he calls "light green" laws, two of which are the National Environmental Policy Act (NEPA) and the National Historic Preservation Act (NHPA). These laws are supposed to protect the public from actions of our government by requiring the government to take into consideration its effects on the environment. (I admit I struggled with "all those bloody acronyms" in place of long titles, even though King went to great care to spell them out at the start of each chapter. I found a "cheat-sheet" lessened the confusion, a condition Dr. King described that was used by the agencies to further befuddle the public.) He summarizes these acts and how they have turned into failures by citing real life examples based on his forty years experience in the field. One of the glaring problems with environmental impact assessment and CRM work is that the clients whose impacts they are studying hire the firms that perform these services. Talk about a conflict of interest!

Dr. King concludes by making recommendations to the current U.S. President, telling agencies to in effect "clean up their act." Oh, he adds that there could be new laws passed to improve the situation, even going so far as to discuss amending the constitution, but the real focus goes back to the bureaucracies that we have created to oversee our cultural environment laws.

Dr. King's latest book is probably not going to make any bestseller list. However, I readily recommend it, along with his more scholarly texts, to all parties concerned with the protection of our cultural heritage.

\section{References Cited}

King, Thomas F.

2000 Federal planning and Historic Places: The Section 106 Process. AltaMira Press, Lanham, Maryland.

2002 Thinking About Cultural Resource Management: Essays from the Edge. AltaMira Press, Walnut Creek, California.

2003 Places That Count: Traditional Cultural Properties in Cultural Management. AltaMira Press, Walnut Creek, California.

2004 Cultural Resource Laws and Practice: An Introductory Guide. 2nd Edition. AltaMira Press, Walnut Creek, California.

2005 Doing Archeology: A Cultural Resource Management Perspective. Left Coast Press, Walnut Creek, California. 